\title{
Kan Norge bli røykfritt?
}

Andelen dagligrøykere i Norge i ferd med å falle til under $20 \%$. Antall røykere er likevel redusert med bare om lag 400000 menn (fra 1960) og 150000 kvinner (fra 1975). Den sosiale sammensetningen av dagens dagligrøykere er svært forskjellig fra det den var i1960- og 1970-årene. I tillegg er det mange som røyker av og til, hovedsakelig til fest. Er det realistisk å ha et røykfritt Norge som mål?

Et samfunn helt uten tobakk - det er målsettingen for alliansen Tobakksfritt, som Den norske legeforening er medlem av. Helseminister Anne Grethe Strøm-Erichsen har uttalt at dette er et langsiktig mål. I 1989 var Legeforeningen med på å lansere en handlingsplan for et røykfritt Norge $i$ år 2000. Ved århundreskiftet var det imidlertid fortsatt rundt $40 \%$ dagligrøykere eller avog-til-røykere her i landet. Er denne nullvisjonen fortsatt realistisk?

Utviklingen i tobakksforbruket i Norge har store likhetstrekk med utviklingen i Australia og USA (1). Hvis tilsiget av nye røykere og avgangen fra røykepopulasjonen fortsetter i samme grad som etter 1980, vil det ta nye 30-40 år før andelen røykere $\mathrm{i}$ befolkningen vil bli stabilisert på rundt $10 \%(2,3)$. Dette tilsvarer omtrent dagens nivå for helsepersonell - de som må antas å ha mest kunnskap om røykingens negative effekter på helsen. Kanskje bør en mer realistisk målsetting på kort sikt være å få andelen røykere $\mathrm{i}$ befolkningen ned på det nivå som eksisterer for helsepersonell? Uansett vil røyking fortsatt være blant våre største helseproblemer i overskuelig fremtid - dersom det ikke settes inn tiltak.

\section{Vil nye tiltak gjøre Norge røykfritt?}

Norge skårer høyt på internasjonale rangeringer når det gjelder kontrolltiltak mot røyking (4). Vi har allerede utnyttet de fleste virkemidler som Verdens helseorganisasjon anbefaler, men flere tiltak er under oppseiling. Legeforeningen har foreslått at aldersgrensen for tobakkskjøp heves fra 18 til 20 år, økt tobakksavgift, innføring av bevilling for tobakksforhandlere og å knytte denne til utsalgssteder som fra før har bevilling for salg av øl. Forslaget vil i praksis innebære at åpningstiden halveres og at antall utsalgssteder reduseres fra om lag 18000 til om lag 4000 . Det er videre foreslått at adgangen til å medbringe en kvote avgiftsfri tobakk fra utenlandsreiser bør opphøre - taxfreesalget utgjør ca. $20 \%$ av nordmenns sigarettkonsum.

Alliansen Tobakksfritt har foreslått forbud mot røyking utenfor serveringssteder og på holdeplasser/terminaler for offentlig kommunikasjon. Kreftforeningen har lenge arbeidet for at elever i videregående skole skal pålegges å være røykfri så lenge skoledagen varer. Stadig flere kommuner forbyr røyking i arbeidstiden for sine ansatte.

Helse- og omsorgsdepartementet har varslet at de ønsker å se nærmere på adgangen til å røyke i bil og i nærheten av barn.

Det er lite trolig at disse tiltakene vil føre

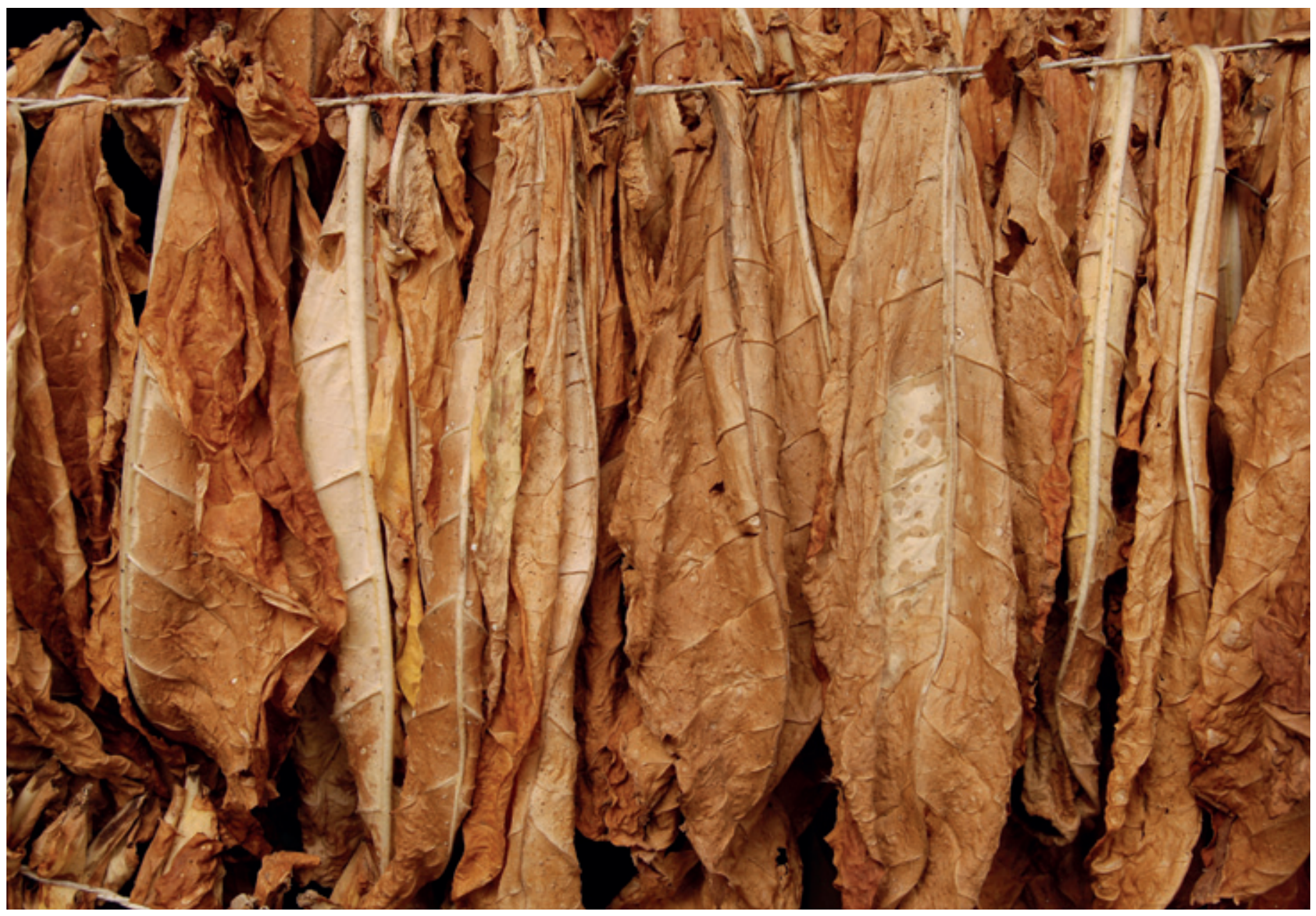


til målet om $10 \%$ røykere i befolkningen. Dette har sammenheng med at røykepopulasjonen allerede har gjennomgått en avskalling. Fire tiår med stadig mer omfattende tobakkspreventive tiltak har resultert i 700000 forhenværende røykere. Vi står igjen med en kjerne røykere som antakelig blir stadig mindre mottakelige for restriksjoner og kampanjer (5). Noen lever under omstendigheter som nedsetter deres evne til å mestre et slutteforsøk. For andre tas beslutningen om fortsatt røyking etter rasjonell behandling av fordelene veid opp mot ulempene (6).

Dessuten er samfunnet endret. Informasjonskampanjer har ført til at kunnskapsnivået om sigaretters skadevirkninger er høyt. Innføringen av adgangsbegrensninger har gjort at røyking betraktes som et sosialt avvik på stadig flere arenaer. Til sammen har disse tiltakene dannet sterke tobakksnegative samfunnsnormer som i begrenset grad kan forsterkes ytterliggere med enda flere restriksjoner. Røykernes motstand mot flere salgs- og adgangsbegrensninger er større enn tidligere (7). Dette øker risikoen for lav etterlevelse av nye tiltak og resulterer dermed i redusert effekt. I Irland holdt andelen røykere seg stabil etter at landet satte i verk Europas mest tobakksrestriktive politikk (8).

\section{Finnes det alternativer?}

Troen på et tobakksfritt samfunn finner lite støtte i atferdsforskning om røyking. Denne «kapitulerende» holdningen blant forskere kan ses på som en erkjennelse av at nytten av å intensivere eksisterende virkemidler er avtakende. Dette skyldes både et mer tobakksnegativt samfunn, endret sosial sammensetning av gruppen røykere og matematiske fremskrivninger basert på rater for tilsig og avgang. Flere forskere har isteden lansert utradisjonelle virkemidler for å redusere forekomsten av tobakksrelaterte sykdommer. Disse forslagene har provosert flere tilhengerne av nullvisjonen. Forslagene gjelder blant annet nedregulering av nikotininnholdet i sigaretter (produktkontroll), overgang til mindre farlige tobakksprodukter for «uhelbredelige» nikotinister (skadereduksjon) og frislipp av mer virksomme nikotinprodukter fra legemiddelindustrien og andre tilbydere.

Den anerkjente tobakksforskeren Kenneth Warner har i flere artikler påpekt at ytterligere restriksjoner, informasjon og særavgifter vil være utilstrekkelig for å få ned andelen røykere i vestlige land til 10\% $(9,10)$. For å redusere den omfattende tobakksrelaterte dødeligheten har Warner drøftet et alternativt scenario der legemiddelindustrien blir gitt vilkår som gjør at de kan produsere «rene» nikotinprodukter i konkurranse med sigaretter og snus, men uten disse produktenes skadelige tilsetningsstoffer (8). Han ser blant annet for seg en sigarettliknende inhalator som kan avgi nikotin direkte til lungene i like store doser som sigarettene. Potensialet for opprettholdelse av avhengighet vil være langt høyere enn ved bruk av dagens farmasøytiske nikotinprodukter, som har hatt liten effekt volum reduseres, slik Tobakksfritt og andre ønsker. Men dette er lite realistisk, i alle fall på kort sikt. Et mer pragmatisk, men kanskje også provoserende alternativ er å stimulere til endret markedssammensetning.

\section{«Vi må betrakte røyking som en kronisk lidelse som trenger livslang medisinering»}

i randomiserte studier (11) og ingen effekt på befolkningsnivå (12). Hvis slike produkter skal kunne markedsføres, må vi begynne se på nikotinavhengighet som et akseptabelt alternativ til sigarettavhengighet. Vi må betrakte røyking som en kronisk lidelse som trenger livslang medisinering - på samme måte som pasienter med hypertensjon trenger blodtrykksmedisin.

For at røykere skal motiveres til overgang til slike nye produkter, understreker Warner at vrangforestillingene om nikotinets skadepotensial må korrigeres - nikotin $i$ ren form er ikke er spesielt skadelig ved lav eksponering. I tillegg må nikotinproduktene gjøres attraktive og ha de samme identitetsformative funksjoner som sigarettene. En ekspertgruppe utgått av toneangivende britiske helseorganisasjoner har anbefalt å stimulere til kommersiell produksjon av slike «rene» nikotinprodukter, gi dem bedre konkurransebetingelser, inkludert lavere avgift enn tobakk, og å gjøre dem tilgjengelige og sosialt akseptable (13).

\section{Vil grensene mellom legemiddel- og tobakksindustri utviskes?} Dagens nikotinprodukter fra legemiddelindustrien har få bivirkninger og lavt potensial for avhengighet. Det vil være problematisk for denne industriens omdømme om en ny generasjon preparater vil bli assosiert med avhengighet og misbruk. Både legemiddelindustrien og snusindustrien lager nikotinprodukter basert på tobakksplanten, men med langt lavere skadepotensial enn produktene fra sigarettindustrien (14). Mens legemiddelindustrien betraktes som en alliert i kampen mot tobakksskadene, anses snusindustrien, forståelig nok, som en kynisk profitør, fordi deres produkter også lages for ungdom uten forutgående røykeerfaring.

Warner ser for seg at vi i fremtiden kan komme til å måtte forholde oss til et nikotinmarked hvor disse tre aktørene slåss om andeler og kjøper seg inn i hverandres virksomheter. Nylig ble legemiddelfirmaet Niconovum kjøpt av det multinasjonale sigarettkonsernet Reynolds. Av alle nikotinprodukter har nikotinlegemidler i dag en markedsandel på 1-2\% (i vestlige land), snusmarkedet er på rundt $25 \%$ (i Norge) og markedsandelen til de livsfarlige sigarettene er på om lag $73 \%$ (i Norge). Det ideelle er selvsagt at nikotinmarkedets total-
Visjonen om et tobakksfritt samfunn kan stå i veien for tiltak som kan redusere tobakksrelatert dødelighet.

\section{Karl Erik Lund \\ kel@sirus.no \\ Statens institutt for rusmiddelforskning \\ Postboks 565 Sentrum \\ 0105 Oslo}

Oppgitte interessekonflikter: Ingen

\section{Litteratur}

1. Lund KE, Lund M, Bryhni A. Tobakksforbruket hos kvinner og menn 1927-2007. Tidsskr Nor Legeforen 2009; 129: 1871-4.

2. Gartner CE, Barendregt JJ, Hall WD. Predicting the future prevalence of cigarette smoking in Australia: how low can we go and by when? Tob Control 2009; 18: 183-9.

3. Mendez D. Warner KE. Commissioned simultation modeling of smoking prevalence as an outcome of selected tobacco control measures. Appendix K. I: Bonnie RJ, Stratton K, Wallace RB, red. Ending the tobacco problem: a blueprint for the nation Washington D.C.: National Academic Press, 2007: $599-640$

4. Joossens L, Raw M. The tobacco control scale: a new scale to measure country activity. Tob Control 2006; 15: 247-53.

5. Warner KE, Burns DM. Hardening and the hard core smoker: concepts, evidence and implications. Nicotine \& Tobacco Research 2003; 5: 37-48.

6. Viscusi KW. Smoking. Making the risky decision. New York: Oxford University Press, 1992.

7. Halvorsen C. Motstand mot flere røyketiltak. Avisenes nyhetsbyrå (ANB) 20.11.2010. www.siste.no/ Innenriks/politikk/article5389303.ece (26.11.2010)

8. Office of Tobacco Control. Ireland: current trends in cigarette smoking. www.otc.ie/research.asp (26.11.2010)

9. Warner KE. Charting the science of the future. Where tobacco control research must go. Am J Prev Med 2007: 33: S314-7.

10. Warner KE. Mendez D. Tobacco control policy in developed countries: yesterday, today and tomorrow. Nicotine \& Tobacco Research 2010; 12: $876-87$

11. Stead LF, Perera R, Bullen $C$ et al. Nicotine replacement therapy for smoking cessation. Cochrane Database Syst Rev. www.ncbi.nlm.nih.gov/ pubmed/18253970 (26.11.2010).

12. Cummings KM, Hyland A. Impact of nicotine replacement therapy on smoking behavior. Ann Rev Public Health 2005; 26: 583-99.

13. Beyond Smoking kills: protecting children, reducing inequalities. London: Cancer Research UK, British Heart Foundation, Action on Smoking and Health, 2008.

14. Clearing the smoke. Assessing the science base for tobacco harm reduction. Institute of Medicine. Washington D.C.: National Academy Press, 2001.

Mottatt 26.11. 2010, første revisjon innsendt 19.1. 2011, godkjent 10.2. 2011. Medisinsk redaktør Petter Gjersvik. 